Uniwersytet Warmińsko-Mazurski

Wydział Nauk o Zdrowiu

DOI: $10.13166 / J M S / 103110$

lukasz.puchala@uwm.edu.pl

IRENEUSZ SOŁTYSZEWSKI

Uniwersytet Warmińsko-Mazurski

Wydział Nauk o Zdrowiu

ireneusz.soltyszewski@uwm.edu.pl

\title{
Pharmaceutical Chambers in The PUbliC HEALTH PROTECTION SYSTEM
}

\section{SAMORZĄD APTEKARSKI W SYSTEMIE OCHRONY ZDROWIA PUBLICZNEGO}

\begin{abstract}
Aim: to determine the actual role of Pharmaceutical Chamber in the health care system, in particular in eliminating the pathological activities of the own members.

Material and methods: the work indicates the scope of cases and penalties being applied by the above-mentioned bodies in the District Pharmaceutical Chamber in Olsztyn over the current and past tenure.

Results: The obtained information points to the activity of the organization, which limits socially disadvantaged phenomena that have an impact on the health security of the society.

Conclusions: Pharmaceutical chambers are a form of professional association of pharmacists performing profession in the Republic of Poland, and membership in them is a prerequisite for obtaining the right to practice, which allows you to work in the profession of public trust. In changing economic and social circumstances, the role and perception of the profession changes, and local government organizations acting on the basis of the Acts provide the opportunity to exercise control and support in the proper performance of the profession. Activities carried out by pharmacists should be in accordance with the law and guidelines of the Apothecary Code of the Republic of Poland. The Pharmaceutical chamber uses own bodies authorized to evaluate the activities of members of the Chambers such as the Pharmaceutical Court and the Professional Spokesman.
\end{abstract}




\section{STRESZCZENIE}

Cel: Określenie faktycznej roli pełnionej przez organa samorządu zawodowego farmaceutów w działaniach systemu ochrony zdrowia, w szczególności w zakresie eliminowania patologicznych działań członków samorządu.

Materiał i metody: Praca wskazuje zakres podejmowanych spraw i stosowanych kar przez wymienione organa w Okręgowej Izbie Aptekarskiej w Olsztynie na przestrzeni bieżącej i minionej kadencji.

Wyniki: Uzyskane informacje wskazują na aktywne działania samorządu, które ograniczają niekorzystne społecznie zjawiska, mające wpływ na bezpieczeństwo zdrowotne społeczeństwa.

Wnioski: Izby aptekarskie stanowią formą zrzeszenia zawodowego aptekarzy wykonujących zawód na terenie Rzeczypospolitej Polskiej, a przynależność do nich jest warunkiem uzyskania prawa wykonywania zawodu, które umożliwia podjęcie pracy w zawodzie zaufania publicznego. W zmieniających się okolicznościach gospodarczych i społecznych następuje przemiana roli i postrzegania zawodu, a organizacje samorządowe działające na podstawie Ustaw dają możliwość sprawowania kontroli i wsparcia we właściwym wykonywaniu zawodu. Działania realizowane przez farmaceutów powinny być zgodne z literą prawa oraz wskazówkami Kodeksu Etyki Aptekarza Rzeczypospolitej Polskiej. Samorząd wykorzystuje organa upoważnione do oceny działań członków Izb, którymi są Sąd Aptekarski i Rzecznik odpowiedzialności zawodowej.

KeYwords: Pharmaceutical chamber, pharmaceutical care, Pharmaceutical court, Code of Ethics of Pharmacist, profession of public trust

SŁOWA KLUCZOWE: izba aptekarska, opieka farmaceutyczna, sąd aptekarski, Kodeks Etyki Aptekarza, zawód zaufania publicznego

\section{WPROWADZENIE}

W ochronie zdrowia publicznego farmaceuci stanowią jedno z kluczowych ogniw systemu ukierunkowanego na odzyskanie i poprawę zdrowia pacjentów oraz utrzymanie stanu zdrowia przez ogół społeczeństwa. Należy podkreślić, że rola farmaceutów w tym systemie, podobnie jak i innych zawodów medycznych, podlega systematycznym procesom ewolucji, co wiąże się ze zmianą paradygmatu w medycynie w kierunku szeroko rozumianego zapobiegania chorobom (Bogdan, Świeczkowski i Religioni, 2017, s. 260-266). Tradycyjna rola farmaceuty polegała na wydawaniu produktów leczniczych i wyrobów me- 
dycznych, sporządzaniu leków recepturowych i leków aptecznych oraz udzielaniu informacji o produktach leczniczych i wyrobach medycznych.

Nową formą działalności farmaceutów i aptek jest opieka farmaceutyczna (OF). Stanowi ona płaszczyznę współpracy farmaceuty z lekarzem i pacjentem $\mathrm{w}$ celu zapobiegania lub identyfikowania i rozwiązywania problemów związanych ze stosowanymi lekami ordynowanymi wielokrotnie przez kilku specjalistów, aby w efekcie zapewnić pacjentowi prawidłową farmakoterapię (Waszyk-Nowaczyk, Simon i Szukalska, 2013, s. 262-265). Opieka farmaceutyczna ma szczególne znaczenie w leczeniu najczęściej występujących chorób cywilizacyjnych, takich jak np. nadciśnienie tętnicze (Świeczkowski, Krysiński i Merks, 2016, s. 23-27). W ostatnich latach pojawiło się również nowe pojęcie - Pharmaceutical Public Health, które w literaturze przedmiotu definiowane jest jako wkład farmaceuty w zdrowie społeczeństwa. W pewnym uproszczeniu, w kontekście indywidualnego podejścia do pacjenta, możemy także mówić o opiece farmaceutycznej, choć należy podkreślić, iż Pharmaceutical Public Health jest pojęciem szerszym i odnosi się do szeregu działań, takich jak np. programy i protokoły do zarządzania chorobami specyficznych dla danej populacji, które oparte są na analizie danych epidemiologicznych i farmakoekonomicznych, kryteriach stosowania leków, przeglądu stosowania leków oraz strategii zmniejszania ryzyka (Wallink i Isetts, 2005, s. 376-389).

W tym kontekście ulega również zmianie rola i zadania samorządu aptekarskiego $\mathrm{w}$ sprawowaniu pieczy nad należytym wykonywaniem zawodu przez farmaceutów w granicach interesu publicznego (art. 7 ust. 1 pkt 5 Ustawy z dnia 19 kwietnia 1991 o izbach aptekarskich) i zgodnie z zasadami Kodeksu Etyki Aptekarza Rzeczpospolitej Polskiej (Uchwała nr VI/25/2012 VI Krajowego Zjazdu Aptekarzy z dnia 22.01.2012 r.). Jest to szczególnie istotne $\mathrm{z}$ uwagi na fakt, że rynek farmaceutyczny jest miejscem szczególnie narażonym na różnego rodzaju konflikty interesów zwiększający prawdopodobieństwo wystąpienia różnorakich typu zachowań naruszających zasady zapisane w kodeksie (Kaczmarek, 2015, s. 99-108). Celem artykułu jest przedstawienie działań samorządu aptekarskiego w ochronie zdrowia publicznego ze szczególnym uwzględnieniem zagrożeń dla zdrowia i życia pacjentów, które niesie ze sobą nielegalny rynek produktów leczniczych i suplementów diety. Jest to bowiem zjawisko, które nabiera na sile i jest szczególnie groźne 
dla ludzkiego życia i zdrowia. W związku z powyższym niezwykle ważne są wszelkie inicjatywy, między innymi ze strony samorządu aptekarskiego, które będą przyczyniać się do ograniczania tego negatywnego zjawiska w interesie szeroko rozumianego zdrowia publicznego.

Okręgowa Izba Aptekarska w Olsztynie jest jedną z 20 Izb Aptekarskich działających na terenie Rzeczypospolitej Polskiej, a jej struktura organizacyjna jest identyczna jak pozostałych Izb. Problemy, z którymi spotykają się organy Samorządu Aptekarskiego, są podobne jak w innych rejonach kraju, a szczególnym ich rodzajem jest postępująca zmiana struktury właścicielskiej aptek, w której obserwuje się ciągłe zmniejszanie się udziału aptek indywidulanych, których właścicielami są farmaceuci, oraz zwiększanie udziału aptek prowadzonych przez inne podmioty. Wynikająca z tego faktu postępująca ograniczona możliwość aktywności w zakresie objęcia działaniami wszystkich właścicieli aptek przez właściwe organa Izby Aptekarskiej jest obserwowana we wszystkich regionach Polski. Stan aktywności Rzecznika Odpowiedzialności Zawodowej i Sądu Aptekarskiego w omawianej Izbie Aptekarskiej może być odzwierciedleniem ogólnego statusu tych organów w pozostałych Izbach Aptekarskich.

\section{Historia SAMORZĄDU APTEKARSKIEgo}

Początkowo zrzeszanie się aptekarzy miało charakter cechowy, a o przynależności do określonego cechu decydowali rajcowie miejscy. Aptekarze zwykle należeli do cechów skupiających np. złotników i malarzy (Poznań 1489 r., Warszawa 1516 r.) lub piwowarów (Gniezno 1535 r., Kalisz 1690 r.); jedynie w Gdańsku i Krakowie stanowili wolne zawody. Od aptekarzy wymagano dobrego wykonywania leków, a nadzór nad nimi sprawowali lekarze oraz Rada Miasta. Odrębną grupę stanowili tzw. aptekarze królewscy (serwitorzy), którzy nie podlegali radom miejskim. Zaopatrywali oni dwór w słodycze, marcepany, świece do komnat, korzenie do potraw, kosmetyki oraz pomagali przy pogrzebach króla (Kamiński i Wesołowski, 2010, s. 25-36).

W okresie rozbiorów jedynie w zaborze austriackim władze zezwoliły na tworzenie zrzeszeń aptekarzy w formie tzw. gremiów, stanowiące zalążek izby aptekarskiej. Pierwsze gremium aptekarzy powstało w Krakowie w 1802 roku, a po roku 1831 powstały gremia mniejsze, tzw. obwodowe. W roku 
1874 powołano do życia (w miejsce dotychczasowych) Gremium Aptekarzy Galicji Wschodniej z siedzibą we Lwowie oraz Gremium Aptekarzy Galicji Zachodniej (w Krakowie). Gremia reprezentowały wszystkich przedstawicieli aptekarstwa, za cel miały reprezentowanie zawodu wobec władz, obronę interesów aptekarzy, sprawdzanie oraz kwalifikowanie kandydatów ubiegających się o koncesję na apteki, ponadto egzaminowanie praktykantów aptekarskich. Po odzyskaniu niepodległości, w latach 1918-1939, gremia uzyskały nowe nazwy: Gremium Aptekarzy Małopolski Zachodniej i Gremium Aptekarzy Małopolski Wschodniej (Zimmermann, Wengler i Pawłowski, 2009, s. 109-113).

Po zakończeniu pierwszej wojny światowej, w listopadzie 1919 r. spotkali się w Warszawie delegaci różnych organizacji aptekarskich działających na ziemiach polskich. Powołano wówczas Związek Zawodowy Farmaceutów Pracowników Rzeczypospolitej Polskiej z siedzibą w Warszawie i oddziałami w całym kraju. W tym samym roku powstała druga organizacja aptekarska Polskie Towarzystwo Aptekarskie. Pomimo tego, że obie organizacje dzieliła różnica interesów - przystąpiły one wspólnie do działań w sprawie powołania izb aptekarskich. W 1938 r. Sejm RP uchwalił ustawę o wykonywaniu zawodu aptekarza, która precyzowała między innymi, kto może wykonywać tę profesję, kiedy traci prawo do wykonywania zawodu, jakie czynności wchodzą w zakres wykonywania zawodu, a także, jak wygląda nabywanie i utrata uprawnień do zarządzania apteką.

W 1939 r. uchwalono ustawę o izbach aptekarskich, która regulowała zasady przynależności do samorządu zawodowego. Zgodnie z tą ustawą, samorząd aptekarski stanowił reprezentację społecznych, gospodarczych i zawodowych interesów tej korporacji. Do jego zadań należało prowadzenie ewidencji aptek, ewidencji osób wykonujących zawód aptekarza, krzewienie oraz strzeżenie zasad etyki i deontologii, a także sądownictwo dyscyplinarne i polubowne. Określono strukturę samorządu, którą tworzyły Izby Okręgowe i wyposażona w osobowość prawną Naczelna Izba Aptekarska. Ustawa ta ze względu na wybuch wojny nie weszła w życie.

W miarę wyzwalania ziem polskich spod okupacji niemieckiej, środowisko aptekarskie przystąpiło do odbudowania struktur samorządu zawodowego. Już w lipcu 1944 powstała w Lublinie pierwsza izba aptekarska. 
W następnych miesiącach powstały kolejne struktury, których łącznie powstało 14. W grudniu 1946 r. Minister Zdrowia wydał rozporządzenie o utworzeniu okręgowych izb aptekarskich, co usankcjonowało oddolny ruch tworzenia struktur samorządu aptekarskiego. Następnym krokiem były wybory Naczelnej Izby Aptekarskiej oraz izb okręgowych przeprowadzone zgodnie zapisami ustawy z 1939 r. W latach 1945-1948 pozwalano również na tworzenie prywatnych aptek na zasadzie dzierżawy lub wykupu. Niestety, po 1948 roku nastąpiła radykalna zmiana nastawienia do samorządów zawodowych, w tym również do aptekarzy. Władze państwowe w ramach tzw. bitwy o handel rozpoczęły akcje przejmowania aptek, hurtowni i wytwórni farmaceutycznych na własność państwa.

W 1951 r. weszła w życie ustawa o zniesieniu izb aptekarskich. Zarówno ten akt prawny, jak i ustawa o przejęciu aptek na własność państwa z $1951 \mathrm{r}$. radykalnie zmieniły obraz polskiego aptekarstwa. Apteki włączono wtedy do Centralnego Zarządu Aptek, a następnie wprowadzono przymusowe zatrudnienie aptekarzy bez możliwości wyboru placówki (Ustawa z dnia 8 stycznia 1951 o przejęciu aptek na własność państwa oraz Ustawa z dnia 8 stycznia 1951 o zniesieniu izb aptekarskich). Taki stan rzeczy trwał do 23 grudnia 1988 r., gdy sejm PRL przyjął ustawę o działalności gospodarczej. Najlepsze apteki szybko trafiły w ręce prywatne, a na inne w kwietniu 1989 r. ogłoszono koncesję. Fala przemian ustrojowych przyniosła również odnowienie działań organizacji aptekarskich. Zgodnie z art. 72 Ustawy o Izbach Aptekarskich z dnia 19.04.201991 r. Dz.U. nr 41 z dnia 14.05.1991 r., Minister Zdrowia i Opieki Społecznej na wniosek Polskiego Towarzystwa Farmaceutycznego i związków zawodowych, powołał Komitet Organizacyjny Izb Aptekarskich. (Łazowska i Murawska, 2011). Od tej pory rozpoczął się nowy etap rozwoju odrodzonego Samorządu Aptekarskiego, w którym działające Rady Aptekarskie sprawują mandat 7 kadencji.

\section{POZYCJA USTROJOWA SAMORZĄDU ZAWODOWEGO}

Podstawą prawną istnienia samorządów zawodowych, w tym i aptekarzy, jest art. 17 ust. 1 Konstytucji Rzeczypospolitej Polskiej, zgodnie z którym w drodze ustawy można tworzyć samorządy zawodowe, reprezentujące osoby wykonujące zawody zaufania publicznego i sprawujące pieczę nad należytym 
wykonywaniem tych zawodów w granicach interesu publicznego i dla jego ochrony. Ratio legis tego przepisu było stworzenie samorządów zawodowych jako zdecentralizowanego komponentu administracji publicznej, któremu powierzono rolę pomocniczą w realizacji zadań publicznych zleconych przez państwo (Szymański, 2013, s. 21-26).

Zgodnie bowiem z zasadą subsydiarności, aktywność państwa, jego instytucji i organów powinna zostać ograniczona tam, gdzie równie wydajne i skuteczne okazuje się działanie obywateli i grup społecznych. Ustawodawca uznał bowiem, że samorządy zawodowe stanowią jedną z podstaw instytucji demokratycznego państwa prawnego ze względu na jego istotną rolę społeczną i mają znaczenie ustrojowe. W związku z powyższym, zapewniono samorządom autonomiczność i samodzielność w wykonywaniu powyższych zadań.

Należy podkreślić, że jakość świadczonych obywatelom usług szczególnie w obszarze zdrowia publicznego jest sprawą o kluczowym znaczeniu dla państwa. Za stworzeniem samorządów realizujących zadania w tym obszarze przemawiają wartości zapisane w ustawie zasadniczej, takie jak: bezpieczeństwo zdrowotne, ochrona życia jednostki, ochrona przed nieuprawnionymi eksperymentami medycznymi oraz prawo do świadczeń zdrowotnych. W tym kontekście w interesie publicznym jest zapewnienie zdrowia obywateli i opieka nad chorymi i dlatego powstałe samorządy tworzące zawody medyczne dają gwarancję należytej jakości usług świadczonych w interesie publicznym (Zimmermann, Wengler i Pawłowski, 2009, s. 109-113).

Wśród 17 zawodów zaufania publicznego tworzących samorządy najliczniejszą grupę stanowią zawody związane z ochroną zdrowia. Należą do nich lekarze, pielęgniarki i położne, farmaceuci, psycholodzy, diagności laboratoryjni oraz fizjoterapeuci.

Należy zwrócić uwagę, że w polskich przepisach prawa brak jest legalnej definicji pojęcia „zawód zaufania publicznego”, co w praktyce rodzi pewne problemy podczas kwalifikowania zawodów do tego typu profesji. Brak legalnej definicji zawodu zaufania publicznego starają się uzupełnić doktryna i orzecznictwo, których przedstawiciele podejmują próby wskazania cech charakterystycznych dla tego typu profesji (Kłusek, 2016, s. 44-56). Według H. Izdebskiego, zawody zaufania publicznego charakteryzują się następującymi cechami: regulowany charakter, zdolność do autoregulacji i do samo- 
regulacji środowiskowej, określone standardy postępowania, posiadanie kodeksu etycznego, a także rzeczywiste funkcjonowanie zawodu w praktyce. Z kolei J. Hausner i D. Długosz podkreślają, że niezbędnymi elementami pojęcia zawodu zaufania publicznego są: niepodleganie regułom hierarchii urzędniczej, występowanie sformalizowanej deontologii zawodowej oraz wymóg posiadania bardzo wysokich wymogów etycznych kształtowanych przez samo środowisko (Karkowska, 2012, s. 267).

W praktyce samorządy zawodowe same zarządzają swoimi sprawami, wszyscy członkowie mają zagwarantowany wpływ na działalność korporacji poprzez wybrane i ustanowione przez siebie organy związku.

Samodzielność zrzeszenia przejawia się w możliwości normowania życia wewnętrznego związku, w drodze jednostronnych aktów. Działalność samorządów zawodowych dotyczy takich kwestii, jak wpływ na wstępowanie do samorządów zawodowych nowych członków, którymi mogą być tylko osoby uprawnione do wykonywania zawodu. Ważną kwestią jest działalność szkoleniowa i permanentne podnoszenie poziomu profesjonalnego i doskonalenia zawodowego. Samorząd zawodowy zobligowany jest również do ustalenia standardów wykonywania zawodu oraz kontroli profesjonalnej i etycznej jakości dostarczanych usług.

Należy również podkreślić, że przyjęte zasady wykonywania zawodów medycznych mają charakter obligatoryjny, a głównym celem działalności samorządu aptekarskiego jest sprawowanie pieczy nad należytym wykonywaniem zawodu farmaceuty (Wyrok Wojewódzkiego Sądu Administracyjnego w Warszawie z dnia 3 marca 2015 r., VI SA/Wa 3285/15). Wyposażenie samorządu zawodowego w określony stopień samodzielności nie wyklucza nadzoru nad prawidłowością funkcjonowania tego rodzaju zrzeszeń publicznoprawnych. Każde działanie samorządu zawodowego podlega ocenie z punktu widzenia interesu publicznego i jego ochrony (Wyrok TK z 23 kwietnia 2008 r., SK 16/07).

\section{ROLA I ZADANIA SAMORZĄDU APTEKARSKIEGO}

Podstawowy zakres działań i powinności samorządu wynikają z zapisów ustawy o Izbach Aptekarskich. Obejmuje on szereg aktywności realizowanych w wieloraki sposób. 
Stwierdzanie i wydawanie prawa wykonywania zawodu farmaceuty jest zadaniem, które ustawodawca powierzył samorządowi aptekarskiemu. Rozwinięciem tego obowiązku jest prowadzenie rejestru farmaceutów posiadających prawo wykonywania zawodu. Szczególnym zadaniem, realizowanym we współpracy z Wojewódzkim Inspektorem Farmaceutycznym, jest także wydawanie opinii w sprawach udzielania lub cofania zezwoleń na prowadzenie aptek lub hurtowni. Samorząd aptekarski, jako strażnik zawodu farmaceuty, występuje w obronie interesów indywidualnych i zbiorowych członków izb aptekarskich. Posiada także możliwości rozstrzygania sporów pomiędzy członkami izby poprzez sąd polubowny, a także orzekania w sprawach o zarzuty dotyczące przewinień zawodowych.

Bardzo ważnym zadaniem jest uczestniczenie przedstawicieli Naczelnej Izby Aptekarskiej w procesach legislacyjnych dotyczących farmaceutów, reprezentowanie zawodu aptekarza na forum publicznym, zapewnienie warunków do poprawy możliwości i jakości wykonywania zawodu. Przykładem takich działań jest obecność przedstawicieli Naczelnej Rady Aptekarskiej w zespołach opracowujących zmiany prawa farmaceutycznego oraz pilotażu opieki farmaceutycznej. Szczególne znaczenie miała aktywność przedstawicieli środowiska farmaceutycznego w pracach legislacyjnych mających na celu wprowadzenie do porządku prawnego nowej regulacji stanowiącej, że wyłącznie farmaceuta może być właścicielem apteki (zasada „apteka dla aptekarza”). Podnoszony od wielu lat postulat środowiska aptekarskiego znalazł potwierdzenie w wyroku Europejskiego Trybunału Sprawiedliwości z 19 maja 2009 r. (w sprawie C-531/06 oraz w sprawach połączonych C-171/07 i in.), który uznał, że posiadanie i prowadzenie apteki może być zastrzeżone wyłącznie dla farmaceutów. Aptekarze reprezentują swój zawód, biorąc udział w spotkaniach organizacji pozarządowych związanych z ochroną zdrowia, konsumenckich oraz przedsiębiorców działających w branży farmaceutycznej.

Należy również podkreślić, że farmaceuci czynnie uczestniczą w ochronie zdrowia publicznego, nie tylko poprzez sporządzanie i wytwarzanie produktów leczniczych, ocenę jakości leków, sporządzanie leków recepturowych i leków aptecznych w aptekach, ale również poprzez sprawowanie opieki farmaceutycznej, w której farmaceuta współpracuje z pacjentem i lekarzem, uczestnicząc w badaniach nad lekami oraz innych badaniach w dziedzinie farmacji. 
Istotnym działaniem izb służącym realizacji celów postawionych przez ustawodawcę w obszarze podnoszenia kompetencji farmaceutów jest organizowanie posiedzeń naukowoszkoleniowych, zaliczanych do obowiązkowych szkoleń w pięcioletnich okresach rozliczeniowych. Oprócz oczywistego elementu edukacyjnego, stanowią one element integrujący aptekarzy oraz pomagają przekazać informacje służące poprawie jakości wykonywanego zawodu aptekarza. Poprzez organizację spotkań szkoleniowych realizowane są zadania nałożone przez ustawodawcę, związane $z$ informowaniem o zmianach w regulacjach prawnych w wykonywaniu zawodu oraz krzewienie zasad etyki zawodowej.

Izba Aptekarska realizuje opisane statutem działania kulturalne, edukacyjne i społeczne. Stanowią one płaszczyznę do międzypokoleniowych spotkań i stanowią naturalny element przekazywania i utrwalania zasad etyczno-deontologicznych, nie tylko opisanych w Kodeksie Etyki Aptekarza, ale realizowanych w codziennej praktyce przez aptekarzy starszego pokolenia.

\section{KODEKS ETYKI Aptekarza Rzeczypospolitej Polskiej}

Etyka zawodowa jest zbiorem zasad wyznaczających powinność moralną obowiązującą w ramach poszczególnych profesji. Może być formułowana w postaci norm zinstytucjonalizowanych, takich jak kodeksy, przysięgi, ślubowania, lub norm formułowanych jako indywidualne propozycje, luźne bądź uporządkowane w zespół postulatów. Etyka zawodowa wskazuje powinności moralne w zakresie danego zawodu, a moralność traktuje w kategoriach oceny zgodności działania poszczególnych przedstawicieli wybranej profesji w odniesieniu do wytycznych etyki zawodowej. Wytyczne te dotyczą postępowania w sytuacjach dotyczących specyfiki zawodu, ale zawsze odnoszą się do ogólnych norm moralnych (Gogacz, 1998). Biorąc pod uwagę, że nie sposób ująć wszystkich możliwych sytuacji w katalogu norm etycznych, o ogólnym morale zawsze stanowi postępowanie jednostki. Uporządkowany zespół norm etyki zawodowej określa się mianem kodeksu deontologicznego danego zawodu. Kodeks taki jest tworzony na podstawie specyfiki danego zawodu w odniesieniu do ogólnych norm etycznych i dotyczy przede wszystkim zawodów zaufania publicznego. Od osób wykonujących zawody me- 
dyczne społeczeństwo oczekuje wysokich kwalifikacji zawodowych, ciągłego doskonalenia się, a także wysokich standardów etycznych, wynikających z wewnętrznej odpowiedzialności i kształtowanych w miejscu pracy.

Kodeks etyczny to dokument kodyfikujący wartości wspólne członków organizacji, określający zachowania, które uważa się za właściwe, wskazujący na to, co nie jest właściwe, oraz określający sankcje, jakie mogą być orzekane w przypadku niestosowania się do kodeksu (Zbiegień-Maciąg, 2002, s. 217). $Z$ definicji tej wynikają konkretne wymogi dotyczące kodeksów. Wytyczne zawarte w kodeksach wynikają z norm ogólnych; w związku z tym kluczową zasadą aptekarskiej profesji jest zaufanie będące podstawą właściwego rozumienia obowiązków i odpowiedniego ich wykonywania. Inną ważną zasadą jest zasada autorytetu. Wynika ona z zasady zaufania, a dotyczy spójności pomiędzy deklarowanymi zasadami a ich praktykowaniem. W zawodach zaufania publicznego bardzo ważne jest również to, by osoby je wykonujące cieszyły się autorytetem w społeczeństwie. W związku z powyższym Kodeks Etyki Aptekarza w szczególny sposób odnosi się do relacji między pacjentem a aptekarzem, na którym ciąży odpowiedzialność za zdrowie i życie człowieka (art. 6 Kodeksu Etyki Aptekarza Rzeczypospolitej Polskiej z dnia 22 stycznia 2012 r.). Dotyczy to również fachowej i troskliwej pomocy pacjentom, rzetelnego informowania, a także zachowania tajemnicy o pacjencie. Na aptekarzu ciąży nie tylko obowiązek przekazania pacjentowi rzetelnej, pełnej i zrozumiałej informacji o lekach i wyrobach medycznych, ale również ta informacja ma być rzetelna i przekazywana w sposób zobiektywizowany, bez użycia manipulacji i ukrywania wiadomości o ewentualnym ryzyku łączącym się ze stosowaniem leku. Taka manipulacja jest nie do przyjęcia, tym bardziej, gdy wynika z przyczyn finansowych (art. 7 ust. 2 Kodeksu Etyki Aptekarza Rzeczypospolitej Polskiej z dnia 22 stycznia 2012 r.). Porada aptekarska to praktyczna działalność zawodowa farmaceuty, która ma na celu udzielanie zainteresowanej osobie w aptece rad i wskazówek dotyczących profilaktyki zdrowia i stosowania w samoleczeniu najwłaściwszych środków farmaceutycznych dostępnych bez recepty. Udzielić porady, wskazać sposób postępowania $\mathrm{w}$ niedyspozycji zdrowotnej, doradzać użycie jakiegoś leku - to niezwykła odpowiedzialność zawodowa, prawna i moralna (Waszyk-Nowaczyk i Simon, 2009, s. 772-774). 
Wydaje się oczywiste, że - aby udzielać kompetentnej pomocy pacjentom - obowiązkiem aptekarza jest ciągłe doskonalenie swoich kompetencji. Niemniej kodeks stwierdza również, że aptekarz nie może przekraczać swoich kompetencji w zakresie wykonywania usług, do których nie jest przygotowany merytorycznie. Kodeks odnosi się również do wzajemnych relacji między członkami samorządu, które powinny być oparte na szacunku, jak również dzieleniu się wiedzą i doświadczeniem. Kodeks zwraca uwagę na potrzebę krzewienia wśród młodych aptekarzy odpowiednich postaw i wartości. Aptekarz, wykorzystując swe umiejętności zawodowe i pozycję w społeczeństwie, ma moralny obowiązek uczestniczenia w działaniach na rzecz środowiska naturalnego, szerzenia wiedzy o prozdrowotnym sposobie życia oraz brania udziału w przeciwdziałaniu patologiom społecznym. Należy podkreślić, że aptekarze, podobnie jak i wykonujący inne zawody medyczne, nie są wolni od problemów moralnych. Szczególnie dotyczy to dylematów związanych z pełnieniem podstawowej funkcji, jaką jest realizacja recept lekarskich i wydawanie leków. Problemem jest również udział aptekarzy w procesie medykalizacji społeczeństwa, czyli zjawiska opartego na założeniu, że istnieje lek na każdą dolegliwość. Ma to wymierny efekt w zwiększaniu sprzedaży leków, a co za tym idzie - w osiąganiu większych zysków. Problemem jest również udział aptekarzy w procederze odwróconego łańcucha dystrybucji leków. Te i podobne sytuacje wymagają od aptekarza podejmowania często bardzo trudnych moralnych wyborów, których skutki często mają wymiar prawny (Grychtol, 2015, s. 103-113).

\section{ODPOWIEDZIALNOŚĆ ZAWODOWA APTEKARZY}

Biorąc pod uwagę miejsce aptekarza w systemie ochrony zdrowia i znaczenie świadczonych przez niego usług, popełnienie błędu może skutkować bardzo poważnymi i często nieodwracalnymi konsekwencjami. W świetle prawa farmaceutycznego aptekarz, który popełnił „błąd w sztuce aptekarskiej”, może zostać pociągnięty do odpowiedzialności prawnej, tj. pracowniczej, zawodowej, cywilnej i karnej.

Pod pojęciem „błędu aptekarskiego” należy rozumieć takie postępowanie (czynność lub zaniechanie), które jest sprzeczne z powszechnie uznanymi zasadami wiedzy i praktyki farmaceutycznej w zakresie dostępnym 
dla aptekarza. Jest to kategoria obiektywna, niezależna od konkretnej osoby czy okoliczności. Odnosząc tę definicję do świadczonych przez farmaceutę usług, można wyróżnić następujące rodzaje błędów, które odpowiadają zakresowi usług farmaceutycznych świadczonych w aptekach: błąd w wydawaniu produktów leczniczych i wyrobów medycznych, błąd w sporządzaniu leków recepturowych lub leków aptecznych oraz błąd w udzielaniu informacji o produktach leczniczych i wyrobach medycznych (art. 86 ust. 2 ustawy z dnia 6 września 2001 r. Prawo farmaceutyczne Dz.U.2001 nr 126, poz.1381).

Aptekarze farmaceuci podlegają odpowiedzialności zawodowej przed sądami aptekarskimi za postępowanie sprzeczne z zasadami etyki i deontologii zawodowej oraz przepisami prawnymi dotyczącymi wykonywania zawodu (art. 45 ustawy z dnia 19 kwietnia 1991 r. o izbach aptekarskich Dz.U. 1991 nr 41 poz. 179). Sprawy odpowiedzialności zawodowej aptekarzy rozpatrują okręgowe sądy aptekarskie i Naczelny Sąd Aptekarski. W sytuacji uzyskania wiarygodnej informacji uzasadniającą podejrzenie popełnienia przez aptekarza przewinienia zawodowego rzecznik odpowiedzialności zawodowej wydaje postanowienie o wszczęciu postępowania wyjaśniającego, które co do zasady może być prowadzone do 3 miesięcy. Po wszczęciu postępowania przez rzecznika odpowiedzialności zawodowej do okręgowej izby aptekarskiej wzywany jest obwiniony farmaceuta w celu złożenia wyjaśnień. Wszczęte postępowanie może być przez rzecznika przesłane do sądu dyscyplinarnego bądź też umorzone.

Wskazać także należy, iż istnieje możliwość polubownego rozstrzygnięcia sporu przez okręgowy sąd aptekarski działający jako sąd polubowny (Rozporządzenie Ministra Zdrowia z dnia 31 marca 2003 r. w sprawie postępowania w sprawach odpowiedzialności zawodowej farmaceutów nr 65 poz. 612).

W przypadku skierowania sprawy do sądu dyscyplinarnego, sąd ten może ukarać farmaceutę karami: upomnienia (wpis do rejestru ukaranych na rok od daty uprawomocnienia wyroku), nagany (wpis do rejestru na dwa lata), zawieszenia prawa wykonywania zawodu farmaceuty na okres od trzech miesięcy do trzech lat, jak również pozbawienia prawa wykonywania zawodu. Należy podkreślić, że kara ta zależy od ciężaru gatunkowego naruszenia oraz rozmiaru wyrządzonej szkody. Co istotne, kary upomnienia, 
nagany i zawieszenia prawa wykonywania zawodu pociągają za sobą utratę prawa wybieralności do organów izb aptekarskich, do czasu usunięcia z rejestru wzmianki o ukaraniu. Natomiast kary zawieszenia i pozbawienia prawa wykonywania zawodu powodują dodatkowo, iż stosunek pracy farmaceuty wygasa z mocy prawa. Wygaśnięcie to pociąga za sobą skutki, jakie przepisy prawa wiążą $z$ rozwiązaniem umowy o pracę bez wypowiedzenia, z winy pracownika. Również w przypadku orzeczenia w pierwszej instancji przez sąd aptekarski kary zawieszenia bądź pozbawienia prawa wykonywania zawodu, farmaceuta może być przez ten sąd tymczasowo zawieszony w czynnościach zawodowych. Postanowienie o zawieszeniu wydaje sąd aptekarski z urzędu lub na wniosek rzecznika odpowiedzialności zawodowej i jest ono natychmiast wykonalne. Jeżeli jednak okres tymczasowego zawieszenia trwa dłużej niż trzy miesiące, Naczelny Sąd Aptekarski bada z urzędu zasadność zawieszenia. Dodatkową konsekwencją kary pozbawienia prawa wykonywania zawodu farmaceuty jest skreślenie z listy członków Okręgowej Izby Aptekarskiej bez prawa ubiegania się o ponowne uzyskanie prawa wykonywania zawodu przez okres dziesięciu lat od daty uprawomocnienia się orzeczenia o karze pozbawienia prawa wykonywania zawodu. Wymierzone kary zostają ujawnione nadto w rejestrze ukaranych prowadzonym przez Naczelną Radę Aptekarską. Informacji o ukaraniu udziela się organom Izb Lekarskich oraz osobom i instytucjom posiadającym lub mogącym wykazać interes prawny w uzyskaniu takich informacji. Od prawomocnego orzeczenia wydanego przez Naczelny Sąd Aptekarski $\mathrm{w}$ drugiej instancji kończącego postępowanie w przedmiocie odpowiedzialności zawodowej przysługuje kasacja do Sądu Najwyższego.

\section{Działalność SĄdu Aptekarskiego OkręgoweJ Izby Aptekarskiej W Olsztynie}

Aktywność Rzecznika Odpowiedzialności Zawodowej (zwanego dalej Rzecznikiem) i Sądu Aptekarskiego Okręgowej Izby Aptekarskiej w Olsztynie (zwanego dalej Sądem) była analizowana na podstawie danych statystycznych z lat 2011-2017 udostępnionych przez Biuro Okręgowej Izby Aptekarskiej. Szczegółowe dane z podziałem na sposób rozstrzygnięcia zawiera tabela nr 1 i 2. 
Tabela 1.

Liczba spraw w latach 2011-2015 z podziałem na sposób rozstrzygnięcia

\begin{tabular}{|c|c|c|c|c|}
\hline Rok & Liczba spraw & $\begin{array}{c}\text { Umorzenie } \\
\text { postępowania } \\
\text { wyjaśniającego }\end{array}$ & $\begin{array}{c}\text { Odmowa wszczęcia } \\
\text { postępowania } \\
\text { wyjaśniającego }\end{array}$ & $\begin{array}{c}\text { Skierowanie do } \\
\text { Okręgowego Sądu } \\
\text { Aptekarskiego } \\
\text { wniosku o ukaranie }\end{array}$ \\
\hline 2011 & 1 & 1 & & 1 \\
\hline 2012 & 5 & 4 & & 1 \\
\hline 2013 & 15 & 11 & 3 & 1 \\
\hline 2014 & 13 & 12 & & 3 \\
\hline 2015 & 7 & 4 & & 6 \\
\hline Razem & 41 & 32 & 3 & 1 \\
\hline
\end{tabular}

Tabela 2.

Liczba spraw w latach 2015-2017 z podziałem na sposób rozstrzygnięcia

\begin{tabular}{|c|c|c|c|c|c|}
\hline Rok & $\begin{array}{c}\text { Liczba } \\
\text { spraw }\end{array}$ & $\begin{array}{c}\text { Umorzenie } \\
\text { postępowania } \\
\text { wyjaśniającego }\end{array}$ & $\begin{array}{c}\text { Odmowa } \\
\text { wszczęcia } \\
\text { postępowania } \\
\text { wyjaśniającego }\end{array}$ & $\begin{array}{c}\text { Skierowanie do } \\
\text { Okręgowego Sądu } \\
\text { Aptekarskiego } \\
\text { wniosku o ukaranie }\end{array}$ & W toku \\
\hline 2016 & 13 & 11 & - & 2 & - \\
\hline 2017 & 18 & 12 & 4 & - & 2 \\
\hline 2018 & 6 & - & 3 & 3 & - \\
\hline Razem & 37 & 23 & 7 & 5 & 2 \\
\hline
\end{tabular}

Tematyka poruszanych spraw byłą szeroka, w wielu przypadkach stwierdzano więcej niż jedną nieprawidłowość. W latach 2011-2015 sprawy obejmowały głównie zarzuty zgłaszane przez Wojewódzkiego Inspektora Farmaceutycznego po przeprowadzonych kontrolach lub po skargach złożonych przez pacjentów. Większość spraw dotyczyła nieprawidłowości w prowadzeniu apteki, m.in. braków leków psychotropowych, braków leków w magazynie, braku w archiwum zarejestrowanych recept, nienależyty nadzór nad technikiem farmaceutycznym, niewłaściwego przechowywania leków, np. braku termometru i higrometru w pomieszczeniu, przechowywania leków w otwartych szafkach poniżej $60 \mathrm{~cm}$ od podłogi, braku ewi- 
dencji środków odurzających. Jedna sprawa dotyczyła wykonywania pracy pod wpływem alkoholu. Dwie sprawy dotyczyły wydania leku bez recepty w sytuacji, gdy jest ona wymagana, oraz błędnego wydania leku.

Poważną grupę spraw stanowiły zarzuty dotyczące niedozwolonego obrotu lekami, tzw. „odwróconego łańcucha dystrybucji”. W tego typu sprawach zadaniem Rzecznika i Sądu jest udowodnienie Kierownikowi apteki świadomego udziału w procederze. W większości jednak przypadków, sprawa dotyczy aptek prowadzonych przez przedsiębiorców niebędących aptekarzami, którzy prowadzą nielegalny wywóz leków z pominięciem placówki aptecznej. W takich sytuacjach właściciel apteki nie podlega odpowiedzialności zawodowej. W sytuacji, gdy Rzecznik nie może udowodnić farmaceucie świadomego udziału w procederze, tego typu sprawy są umarzane.

Warto zauważyć, że w bieżącej kadencji znacząco spadła liczba tego typu spraw. Można wysunąć przypuszczenie, że jedną z przyczyn spadku intensywności niekorzystnego społecznie zjawiska jest aktywność sądu i rzecznika, piętnująca takie działania. Znaczący wpływ miały również działania inspekcji farmaceutycznej oraz zmiana przepisów prawnych, określających dokładnie, jakie praktyki zostały zakazane.

Nowym problemem, z którym spotyka się rzecznik i sąd, są zarzuty o niedozwoloną reklamę apteki, co wynika $z$ art. 94 Ustawy Prawo farmaceutyczne. Ponownie w tym przypadku, właściciel niebędący farmaceutą nie podlega organom Izby Aptekarskiej, a rzecznik nie może udowodnić winy kierownika apteki w sytuacji, gdy przedsiębiorca np. kolportuje ulotki na osiedlach mieszkaniowych w pobliżu apteki, co skutkuje brakiem odpowiedzialności zawodowej za takie naruszenie. Warto zauważyć, że farmaceuta będący właścicielem apteki podlega karom przewidzianym w regulacjach dotyczących Sądu Aptekarskiego i stosowanie niedozwolonych praktyk naraża go na konsekwencje.

Znacząca większość spraw w bieżącej kadencji obejmowała nieprawidłowości w prowadzeniu apteki dotyczące między innymi: obecności w magazynie leku przeterminowanego, wydawania leku bez wymaganej recepty, stosowania wag, dla których upłynął okres legalizacji, czy też organizacji pracy w aptece. Działania Sądu rozpoczynają się po przekazaniu sprawy przez rzecznika. W latach minionej kadencji 2011-2015 sąd rozpatrzył 5 spraw skierowanych przez rzecznika i wydał 4 wyroki. 
Trzech aptekarzy zostało ukaranych naganą, w jednym przypadku zastosowano karę upomnienia. W jednym przypadku Sąd zdecydował o uniewinnieniu oskarżonego. Jedna ze spraw, rozpoczęta w 2014 r., znalazła swój finał w 2016. W bieżącej kadencji Sąd rozpatrzył 5 spraw i wydał 6 wyroków (w tym jeden w związku ze sprawą rozpoczętą w poprzedniej kadencji). Sąd czterokrotnie ukarał aptekarza upomnieniem, jeden raz karą nagany oraz umorzył jedno postępowanie.

\section{WNIOSKI}

Działania samorządu zawodowego farmaceutów mające na celu ograniczenie nieprawidłowości wynikających z zaniedbań lub celowych działań farmaceutów stanowią istotny element systemu ochrony zdrowia w Polsce, który obejmuje nie tylko bezpośrednie działania ratujące życie, ale także procesy zapewniające bezpieczeństwo lekowe społeczeństwa. Farmaceuci, jako przedstawiciele zawodu zaufania publicznego, są ważnym elementem systemu ochrony zdrowia, a ich szczególna rola wiąże się z wysokimi wymaganiami prawnymi i etycznymi, które stawia przed nimi samorząd zawodowy na mocy uprawnień nadanych przez ustawodawcę. Umożliwione przez ustawodawcę prowadzenie aptek przez przedsiębiorców niebędących farmaceutami spowodowało znaczące utrudnienia w egzekwowaniu zasad etycznych i należnego prowadzenia apteki, poprzez fakt niepodlegania przedsiębiorców organom Izb Aptekarskich. Z drugiej zaś strony stawia farmaceutę prowadzącego aptekę w sytuacji pełnej odpowiedzialności zawodowej za podobne przewinienia.

\section{Literatura}

Bogdan, M., Świeczkowski, D., Religioni, U. (2017). Rola farmaceuty w polskim systemie ochrony zdrowia w kontekście ochrony zdrowia publicznego. „Farmacja Współczesna" 2017, nr 10, s. 260-266

Dziennik Urzędowy nr 55 z 1939 r. www.dziennikustaw.gov.pl/du/1939/s/55/346 (dostęp: 20.05.2018).

Gogacz, M., (1998). Czym jest etyka zawodowa. W: A. Andrzejuk (red.), Zagadnienie etyki zawodowej, Warszawa: Oficyna Wydawnicza Navo. ISBN 8390624273. 
Grychtoł, A., (2015). Dylematy moralne polskich aptekarzy. „Annales. Etyka w życiu gospodarczym" 18 (1), s. 103-113. ISSN 1899-2226.

Kaczmarek, E. (2015). Etyczne wyzwania w przemyśle farmaceutycznym. Zarys problematyki. „Annales. Etyka w życiu gospodarczym” 18 (3), s. 99-108. ISSN 18992226.

Kamiński, Z., Wesołowski M. (2010). O dawnych aptekach, „Farmacja Polska”, 66 (1) s. 25-36. ISSN 0014-8261.

Karkowska, D. (2012). Zawody Medyczne. Warszawa: Wyd. Lex a Wolters Kluwer business, s. 267. ISBN 9788326438646.

Kłusek, P. (2016). Fizjoterapeuta jako wolny zawód i zawód zaufania publicznego, „Rozprawy Naukowe Akademii Wychowania Fizycznego we Wrocławiu” (53), s. 44-56. ISSN 0239-4375.

Kodeks Etyki Aptekarza Rzeczypospolitej Polskiej z dnia 22 stycznia 2012 r., ust. 2, art. 6 i 7.

Łazowska, L., Murawska, J. (2011). Okręgowa Izba Aptekarska 1991-2011, Olsztyn: Studio Antykwa. ISBN 9788393389506.

Rozporządzenie Ministra Zdrowia z dnia 31 marca 2003 r. w sprawie postępowania w sprawach odpowiedzialności zawodowej farmaceutów nr 65 poz. 612 .

Szymański, J.Z. (2013). Samorząność zawodów zaufania publicznego w społeczeństwie obywatelskim. W: Samorzad zawodowy $w$ demokratycznym państwie prawa. Materiały z konferencji zorganizowanej przez Komisję Praw Człowieka, Praworządności i Petycji we współpracy z Mazowieckim Forum Samorządów Zawodów Zaufania Publicznego, s. 21-26.

Świeczkowski, D., Krysiński, J., Merks, P. (2016). Rola farmaceuty i miejsce opieki farmaceutycznej w terapii nadciśnienia tętniczego. „Choroby Serca i Naczyń” 13 (1), s. 23-27. ISSN 1733-2346.

Uchwała nr VI/25/2012 VI Krajowego Zjazdu Aptekarzy z dnia 22 stycznia 2012 r.

Ustawa z dnia 8 stycznia 1951 r. o przejęciu aptek na własność państwa.

Ustawa $\mathrm{z}$ dnia 8 stycznia 1951 r. o zniesieniu izb aptekarskich.

Ustawa z dnia 19 kwietnia 1991 r. o izbach aptekarskich. Dz.U. 1991 nr 41 poz. 179, (m.in. art. 45).

Ustawa z dnia 6 września 2001 r. Prawo farmaceutyczne Dz.U. 2001 nr. 126 poz.1381 ust. 2, art. 86 . 
Wallink, D.P., Isetts, B.J. (2005). Becoming "Indespensable": Developing Innovative Community Pharmacy Practices. Jour Amer Pharm Assn (45), s. 376-389.

Waszyk-Nowaczyk, M., Simon, M. (2009). Znaczenie porady farmaceuty w procesie samoleczenia się pacjentów. „Farmacja Polska”, 65(11) s. 772-774. ISSN 0014-8261.

Waszyk-Nowaczyk, M., Simon, M., Szukalska, B., (2013). Opieka farmaceutyczna płaszczyznq współpracy lekarza i farmaceuty. „Nowiny Lekarskie” 82 (3), s. 262-265. ISSN 0860-7397.

Wyrok TK z 23 kwietnia 2008 r., SK 16/07.

Wyrok Wojewódzkiego Sądu Administracyjnego w Warszawie z dnia 3 marca 2015 r., VI SA/Wa 3285/15.

Zbiegień-Maciąg, L. (2002). Etyka w zarzadzaniu organizacją. W: J. Dietl, W. Gasparski, Etyka biznesu. Warszawa: PWN, s. 217. ISBN 8301132663.

Zimmermann, A., Wengler, L., Pawłowski, L. (2009). Prawne aspekty funkcjonowania samorzadu aptekarskiego w Polsce - wybrane zagadnienia. „Prawo w farmacji”, 65 (2), s. 109-113. 
